\title{
Konsep Ketuhanan Dwi Tunggal Siwa-Buddha Bahung Tringan
}

\author{
Oleh: \\ I Gede Suwantana \\ Dosen Fakultas Brahma Widya, IHDN Denpasar \\ Email: gedesuwantana@gmail.com
}

\begin{abstract}
:
The concept of Shiva-Buddha Theology to the Bahung Tringan Community in Karangasem Bali is different from that of the Shiva-Buddha that flourished in Java until the time of Majapahit. Bahung Tringan considers that Shiva-Buddha is within everyone and can be a spiritual process, not two different religions then positioned aligned. According to Ida Wayan Jelantik Oka, the founder of the Community said that in spiritual practice, one who is able to penetrate the final limit of Shivahood will be able to reach the ultimate goal of his life, namely Buddhahood. This work will try to describe how the Siva-Buddha principle that is in each person is processed in a spiritual practice so as to attain Nirvana. The spiritual process that fully takes place in the Shivahood through Tantra, under certain conditions is able to reach the edge of the akasa, the end point of Shiva's realm. With proper and sufficient practice, at one time this edge will be penetrated and then reach Sunya's realm. It is the ultimate achievement of spiritual practice.
\end{abstract}

Keywords: Dwi Tunggal, Siwa-Buddha, Bahung Tringan, Theology

\section{Pendahuluan}

Siwa-Buddha merupakan campuran (sinkretisme) agama Hindu dan Buddha di Indonesia. Pada zaman Majapahit agama Siwa dan Buddha berpadu menjadi satu. Beberapa ahli menyebut bahwa Siwa-Buddha merupakan sebuah sinkritisme, sementara beberapa yang lainnya menyebutnya dengan nama berbeda. Seperti misalnya (diambil dari Phalgunadi, 2013): Pertama, J.H.C Kern yang memfokuskan studinya pada inskripsi-inskripsi berbahasa Sansekerta, prasasti-prasasti berbahasa Jawa Kuna, dan kitab-kitab berbahasa Jawa Kuna menggunakan istilah vermenging (percampuran). Percampuran antara Shiwaisme dan Buddhisme Mahayana terutama terjadi pemberian makna terhadap Prinsip Tertinggi yang Tunggal. Kedua, W.H. Rassers memfokuskan perhatiannya pada struktur masyarakat Jawa purba. Menurutnya kebudayaan Jawa asli dicirikan dengan sistem pembagian dua phratrie, sebagai dua yang azasi. Dia berpendapat bahwa kebudayaan Jawa asli merupakan kemungkinan penyebab terjadinya pertautan antara Siwaisme dan Buddhisme di Jawa.

Ketiga, J.Gonda juga menggunakan istilah "koalisi" dengan menekankan bahwa penyamaanpenyamaan antara dewa-dewa Shiwa dan dewadewa Buddha tidak hanya terjadi di Jawa, tetapi juga di Kamboja, Nepal, dan India sendiri. Oleh karena itu, kebudayaan asli Jawa bukanlah satusatunya kemungkinan pendorong terjadinya koalisi antara Siwa dan Buddha. Sejalan dengan itu, Suwito Santoso berpendapat bahwa Siwaisme dan Buddhisme pada praktiknya masih selalu merupakan agama yang terpisah, sehingga dia juga menggunakan istilah koalisi (coalition). Haryati Soebadio (1982), juga tidak sependapat dengan istilah Sinkritisme untuk menyatakan 
perpaduan Siwa dan Buddha karena istilah ini berkonotasi hilangnya identitas masing-masing agama dan menghasilkan sistem baru.

Keempat, Edi Sedyawati melukiskan pertemuan Hinduisme dan Buddhisme pada masa Jawa Tengah sekitar abad ke-8 dan ke-9 Masehi sebagai "amalgamation" (percampuran) melalui adopsi dan kemudian terjadi "restructuring" (penataan kembali) sesuai dengan alam pikiran kebudayaan Jawa. Artinya, peran kearifan lokal Jawa dalam mempertemukan dan menata kembali ajaran Shiwa-Buddha merupakan faktor yang terpenting.

Widnya (2008) dalam karyanya berjudul: 'Pemujaan Siwa-Buddha dalam Masyarakat Hindu di Bali' menyatakan bahwa sinkretisme Siva-Buddha di Indonesia adalah suatu gejala keagamaan yang sangat komplek. Istilah-istilah: siva-buddha tunggal dan bhinneka tunggal ika, secara khusus, memang bisa memberi indikasi yang kuat tentang sinkretisme antara Sivaisme dan Buddhisme di Indonesia. Tetapi dalam arti yang lebih luas sumber-sumber sastra Jawa Kuna yang memuat istilah-istilah tersebut secara keseluruhan tidak berbicara tentang kemanunggalan di antara kedua sistem keagamaan tersebut. Sehingga dengan demikian, masalah Siva-Buddha tidak sesederhana seperti yang diperkirakan sebelumnya.

Menurutnya, kebanyakan para sarjana menganggap bahwa masalah Siva-Buddha sudah selesai dengan mengutip sumber-sumber yang terbatas dalam kesusastraan Jawa Kuna. Masalah Siva-Buddha bukan terjadi karena diambil begitu saja melalui sumber-sumber arkeologi maupun sumber-sumber sastra. Keberadaannya dalam panggung sejarah karena kontribusi yang diberikan oleh para sarjana, baik para orientalis barat, sarjana India maupun sarjana Indonesia. Itulah sebabnya masalah Siva-Buddha ini menjadi semakin komplek karena diwarnai oleh silang pendapat para sarjana.

Kompleksitas permasalahan tersebut sudah tampak sejak di India, yaitu dengan adanya kenyataan "saling menukar" dewa-dewa di antara agama Hindu, Buddha dan Jaina. Dewa-dewa Hindu seperti Pārvatī dan Indra ditemukan di antara dewa-dewa Jaina, demikian juga dewa Ganapati, Saraswatī, Mahākāla, Nīlakantha, dan sebagainya, terkenal di antara dewa-dewa Buddha. Sementara Hindu meminjam dewa-dewa Buddha seperti Mahācīnatārā, Janguli dan Vajrayogin̄̄ di bawah nama Tārā, Manasā dan Chinnamastā. Kenyataan ini menyulitkan para peneliti untuk memberi batasan yang tegas mengenai sinkretisme antara Sivaisme dan Buddhisme.

Di Indonesia, kesusastraan Jawa Kuno, tidak hanya berbicara tentang penyamaan-penyamaan yang terbatas antara Siva dan Buddha, melainkan juga diantara kelompok-kelompok dewa dalam agama Hindu dan Buddha, di samping penyamaan dewa-dewa dalam intern agama Hindu dan intern agama Buddha secara terpisah tingkat percampuran kedua agama tersebut tidak sama kohesitasnya pada setiap zaman. Artinya, sinkretisme tersebut mengalami evolusi dari satu zaman kepada zaman berikutnya sampai kemudian pada suatu zaman tertentu ada momentum sejarah yang membuatnya menjadi semakin kuat, semakin rekat, sehingga Siva-Buddha, muncul ke panggung sejarah sebagai agama tunggal. Sebagaimana diketahui momentum itu muncul di Jawa Timur pada Zaman Majapahit.

Dalam sejarah kebudayaan Indonesia, evolusi Siva-Buddha dibagi menjadi tiga phase, yaitu phase pertama meliputi evolusi sebelum zaman Majapahit; phase kedua pada zaman Majapahit (1292-1500); dan phase ketiga setelah zaman Majapahit terutama perkembangan kedua sistem yang tertinggi. Pada tataran praksis, realitas pemujaan Siva-Buddha di Bali tidak lebih dari subsistem agama Hindu, hal ini terbukti, tidak hanya karena domain ritual dan upakara sebagai akibat kuatnya pengaruh Siwa Siddhanta, melainkan suatu fakta bahwa para pendeta dari kedua agama tersebut menganut agama Hindu secara formal. Hanya dalam beberapa hal dapat dilihat pengaruh Buddha yang disatukan dengan aspek ajaran Siva Siddhanta, seperti dalam penggunaan genta dan ketu, demikian juga perbedaan dalam menggelung rambut, dan penggunaan beberapa mantra. Semua ini menunjukkan kompleksitas masalah dalam Siva-Buddha. 
Dari semu pandangan di atas, teori atau konsep yang dimunculkan akan sangat bermanfaat di dalam penelitian ini, meskipun pembahasannya menyangkut penyatuan dua agama besar tersebut. Konsep Siwa-Budha yang dimaksudkan di dalam penelitian ini terhadap Komunitas Bahung Tringan adalah dua gugusan alam rohani yang sangat berbeda satu dengan yang lainnya, namun terjalin dalam sebuah ikatan yang tidak bisa dipisahkan. Konsep Siwa-Buddha yang digunakan oleh komunitas Bahung Tringan lebih berupa capaian rohani ketimbang penyatuan dua agama. Meskipun dalam beberapa term tetap mengambil prinsip-prinsip dari penyatuan kedua agama tersebut, namun konteksnya akan sangat berbeda dengan apa yang diajarkan di dalam komunitas Bahung Tringan.

\section{Pembahasan}

Pada tataran teologis-praktis, penyatuan Siwa-Buddha masih berada dalam wilayah agama, sedangkan dalam teo-metafisis, penyatuan yang terjadi ada dalam sebuah proses. Di dalam agama terdapat tata cara pemujaan, keyakinan, permohonan dan objek yang dipuja, yang ada diluar tubuh manusia, sementara dalam sebuah proses, yang ada adalah penciptaan, yakni proses menjadikan dari sesuatu menjadi sesuatu yang lain di dalam tubuh manusia itu sendiri. Penyatuan Siwa-Buddha di dalam Meditasi Kesadaran Buddhi Bahung Tringan ini telah berada di dalam tataran teo-metafisis sebagaimana dinyatakan oleh Ida Wayan Jelantik Oka (Wawancara, 30 Juli 2016) sebagai berikut:

Penyatuan Siwa-Buddha pada masa perkembangan di Jawa Tengah maupun di Jawa Timur dalam kurun waktu lebih dari 700 tahun tersebut masih dalam tataran agama, dimana Agama Siwa itu mengkhusus untuk memuja Hyang Siwa, sedangkan Agama Buddha mengkhusus untuk pemujaan kehadapan Hyang Parama Buddha. Sementara dalam Meditasi Kesadaran Buddhi Bahung Tringan adalah sebuah proses. Dalam pemujaan akan ada pengharapanpengharapan kehadapan Tuhan yang dipuja. Dalam penyatuan Siwa-Buddha di Bahung Tringan tidak ada pengharapan, melainkan penciptaan.

Penyatuan Siwa-Buddha di dalam Meditasi Kesadaran Buddhi Bahung Tringan terjadi di dalam tubuh, tidak di dalam agama. Prinsip teologi tidak berkembang dari teks-teks agama, melainkan muncul dari sebuah proses spiritual di dalam tubuh. Pada saat seorang sadhaka (penekum spiritual) melakukan meditasi, di dalam dirinya terjadi sebuah proses spiritual atau proses pemurnian Buddhi. Dalam proses tersebut penyatuan SiwaBuddha terjadi. Penyatuan Siwa-Buddha yang dimaksudkan di dalam teknik Meditasi Kesadaran Buddhi ini tidak diartikan sebagai sebuah pertemuan kembali dari keterpisahan, melainkan menyadari kembali atas kesatuan Siwa-Buddha yang telah laten ada di dalam tubuh melalui teknik meditasi.

Bahung Tringan memiliki keyakinan bahwa badan itu sebagai Siwa, sementara roh yang ada di dalamnya adalah Buddha. Siwa tidak berhubungan dengan objek pemujaan sebagaimana yang ada di dalam agama melainkan sebuah kesadaran yang sifatnya fisik, sementara Buddha inti dari kesadaran fisik tersebut yang bersifat sunya (keheningan, non-fisik). Dwi Tunggal SiwaBuddha ini di dalam teknik Meditasi Kesadaran Buddhi Bahung Tringan diuraikan oleh Pinisepuh Ida Wayan Jelantik Oka (wawancara, 30 Juli 2016) sebagai berikut:

Dwi Tunggal dalam teknik Meditasi Kesadaran Buddhi Bahung Tringan adalah penyatuan Siwa dan Buddha. Hal yang disebut Siwa dalam teknik ini adalah segala hal yang terlihat oleh mata kasar, segala hal yang dirasakan oleh kulit, segala hal yang dapat diindra oleh panca indra, segala hal yang masih dapat dipikirkan oleh pikiran, semua itu adalah Siwa. Fisik manusia dan pikirannya adalah Siwa. Segala hal yang berada dalam kesadaran fisik adalah Siwa. Atman yang telah diproses secara spiritual adalah Buddha. Proses spiritual yang dimaksudkan adalah suatu aktivitas memproses diri. Siwa itu ibarat santan sementara Buddha ibarat minyaknya. Santan jika diproses akan melahirkan minyak. Disini santan dan minyak pada prinsipnya bersatu namun bukan menyatu. Artinya, jika dipisahkan sangat sulit. Jika 
diambil minyaknya saja, pasti ada yang melekat dalam santan, demikian sebaliknya. Ada garis pemisah sekaligus garis penyatuan di dalamnya. Melalui proses meditasi, Dwi Tunggal SiwaBuddha ini baru memiliki manfaat. Tanpa proses meditasi dia hanya sesuatu yang bersifat potensial saja.

Berdasarkan uraian di atas dapat dilihat adanya perbedaan yang mencolok antara konsep teologi Dwi Tunggal Siwa-Buddha dalam agama yang berkembang di Jawa dan teologi Dwi Tunggal Bahung Tringan. Konsep Dwi Tunggal atau penyatuan Siwa-Buddha dalam kontek agama adalah masing-masing dari agama tersebut kedudukannya disejajarkan di dalam memandang satu kebenaran. Di dalamnya akan ditemukan bahwa jalan manapun yang diambil akan mencapai tujuan yang sama, akan sampai pada satu kebenaran yang sama. Sementara dalam konsep Teologi Dwi Tunggal Siwa-Buddha Bahung Tringan, Siwa dan Buddha tidak disejajarkan melainkan berada dalam satu lingkaran yang sama tetapi memiliki garis pemisah atau garis penghubung, keduanya berbeda, tetapi bersatu. Perbedaan ini dapat digambarkan sebagai berikut.

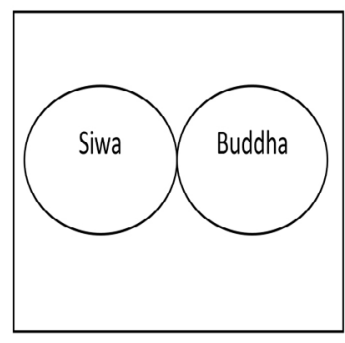

Gambar 5.1: Jaman Majapahit

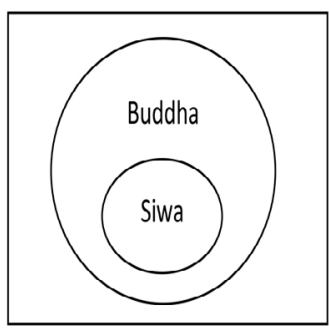

Gambar 5.2: Bahung Tringan
Pada gambar 1 terlihat bahwa dua lingkaran masing-masing kedudukannya sejajar dan berdiri sendiri yang berada di dalam sebuah kotak segi empat. Diandaikan kotak segi empat tersebut adalah kebenaran, maka masing-masing lingkaran tersebut berada di dalam kebenaran yang sama. Baik ajaran agama Siwa maupun ajaran agama Buddha akan mengarah ke arah kebenaran yang sama. Sementara dalam prinsip Dwi Tunggal Meditasi Kesadaran Buddhi Bahung Tringan, kedua lingkaran tersebut masih ada, yakni memiliki batas yang jelas, tetapi telah menjadi satu wadah lingkaran yang lebih besar. Lingkaran di dalam diandaikan Siwa, sementara lingkaran yang ada diluarnya adalah Buddha. Lingkaran Siwa berada di dalam oleh karena seluruh teknik meditasi diaktualisasikan melalui tubuh fisik dimana fisik itu sendiri adalah representasi Siwa.

Penggambaran Dwi Tunggal Siwa-Buddha yang ada di Nusantara, khususnya pada jaman Majapahit seperti tampak pada gambar 1 sesuai dengan bukti-bukti peninggalan yang ada. Candicandi peningalan yang bercorak Siwa dan Buddha bertebaran di Jawa Tengah dan Jawa Timur. Karyakarya sastra juga menunjukkan perbedaan antara karya Sastra yang bercorak Siwa dan bercorak Buddha. Pada saat ini, tradisi di Bali juga masih mewarisi adanya sulinggih dari Tradisi Siwa, Buddha maupun Bujangga Waisnawa. Suamba (2007: 349-352) secara lengkap menggambarkan aspek-aspek yang menyebabkan Siwa dan Buddha mengalami penyatuan di Nusantara khususnya pada era Majapahit sebagai berikut.

Tabel 1 Penyatuan Siwa-Buddha Nusantara

\begin{tabular}{|c|c|c|c|}
\hline $\mathrm{N}_{0}$ & Konsep & Agama Siwa & Agama Buddha \\
\hline 1 & $\begin{array}{l}\text { Prinsip } \\
\text { tertinggi }\end{array}$ & $\begin{array}{l}\text { Parambrahma/ } \\
\text { Sadyotkranti/ } \\
\text { Parama Shiwa/ } \\
\text { AM-AH } \\
\text { (moksa) } \\
\text { Pranawajnana/ } \\
\text { Pranajyotirupa/ }\end{array}$ & $\begin{array}{l}\text { Parama Buddha/ } \\
\text { Advaya/AM-AH } \\
\text { (sumya) } \\
\text { Advaya-Jnana } \\
\text { Divarupa }\end{array}$ \\
\hline 2 & Dwi Tunggal & $\begin{array}{l}\text { Siwa-Durga/ } \\
\text { Shakti }\end{array}$ & $\begin{array}{l}\text { Adhi Budha dan } \\
\text { Pradnyaparamita } \\
\text { (Advaya dan } \\
\text { Advayajnana). }\end{array}$ \\
\hline 3 & $\begin{array}{l}\text { Tiga Hakikat } \\
\text { Shiwa }\end{array}$ & $\begin{array}{l}\text { Tri Purusha: } \\
\text { Paramashiwa } \\
\text { (niskala), } \\
\text { Sadashiwa } \\
\text { (sakala-niskala), } \\
\text { Shiwa (sakala) }\end{array}$ & $\begin{array}{l}\text { Buddha } \\
\text { Vajrasattwa dan } \\
\text { Awalokiteswara } \\
\text { dalam wujud } \\
\text { wujud } \\
\text { Dharmakaya, } \\
\text { Sambhogakaya, } \\
\text { dan Nirmanakaya. }\end{array}$ \\
\hline 4 & $\begin{array}{l}\text { Kelepasan/ } \\
\text { Tujuan } \\
\text { tertinggi. }\end{array}$ & Moksa, Sunya & Sunya, Nirbana \\
\hline 5 & Tiga Dewa & $\begin{array}{l}\text { Tri Murti : } \\
\text { Brahma, Wisnu, }\end{array}$ & $\begin{array}{l}\text { Ratnatraya: } \\
\text { Sakyamuni, }\end{array}$ \\
\hline
\end{tabular}




\begin{tabular}{|c|c|c|c|}
\hline & & Iswara & $\begin{array}{l}\text { Lokeswara, dan } \\
\text { Bajrapani atau } \\
\text { Wairocana, } \\
\text { Amitabha, } \\
\text { Aksobhya, atau } \\
\text { Wairocana, } \\
\text { Ratnasambhawa, } \\
\text { dan Amogasiddhi. } \\
\text { Ketiganya disebut } \\
\text { juga Buddha, } \\
\text { Darma, dan } \\
\text { Sangga, } \\
\text { merupakan esensi } \\
\text { dari Kaya, Wak, } \\
\text { dan Citta (Tri } \\
\text { Kaya). }\end{array}$ \\
\hline 6 & Lima Dewa & $\begin{array}{l}\text { Panca Dewata/ } \\
\text { Panca Brahma: } \\
\text { Sadyojata (Iswara: } \\
\text { Sa), Bamadewa } \\
\text { (Brahma: Ba), } \\
\text { Tatpurusa } \\
\text { Mahadewa:Ta), } \\
\text { Aghora (Wishnu: } \\
\text { A), dan Isana } \\
\text { (Shiwa: I). }\end{array}$ & $\begin{array}{l}\text { Panca Tatagatha: } \\
\text { Wairocana } \\
\text { (tengah), } \\
\text { Ratnasambhawa } \\
\text { (selatan), } \\
\text { Amitabha (Barat), } \\
\text { Amogasiddhi } \\
\text { (utara), dan } \\
\text { Aksobya (Timur). }\end{array}$ \\
\hline 7 & Lima Aksara & $\begin{array}{l}\text { Panca Aksara : } \\
\text { Sang, Bang, Tang, } \\
\text { Ang, Ing. }\end{array}$ & $\begin{array}{l}\text { Panca Aksara: } \\
\text { Ah, Hum, Tram, } \\
\text { Hrih, A. }\end{array}$ \\
\hline 8 & $\begin{array}{l}\text { Dewi Ilmu } \\
\text { Pengetahuan }\end{array}$ & Saraswati & Pradnya Paramita \\
\hline 9 & Pendeta & Dang Acarya & Dang Upadhyaya \\
\hline 10 & Istilah nama & Siwa (Sewa) & $\begin{array}{l}\text { Jina, Buddha, } \\
\text { Sogata. }\end{array}$ \\
\hline
\end{tabular}

Prinsip Dwi Tunggal Siwa Buddha Bahung Tringan memandang bahwa segala sesuatu yang bersifat materi adalah Siwa, sementara aspek non-fisiknya adalah Buddha. Siwa merupakan wadahnya sementara Buddha adalah isinya. Siwa dan Buddha ini bersatu tetapi tetap berbeda berada di dalam volumenya masing-masing. Wadah dan isinya ini dapat bekerjasama untuk mencapai tujuan tertentu. Bentuk kerjasama ini diibaratkan seperti senapan dan pelurunya, sebagaimana yang dinyatakan oleh Ida Wayan Jelantik Oka sebagai berikut:

Siwa adalah fisiknya sebagai wadah, sementara Buddha adalah rohnya sebagai isi. Dwi tunggal dalam konteks ini adalah dipersatukan bukan menyatu. Mereka tetap berada di dalam volumenya masing-masing. Mereka mampu bekerjasama. Ibarat peluru dan senapan, Siwa adalah senapannya, dan Buddha adalah pelurunya. Dengan adanya penyatuan ini, senapan mampu menjadi peledak dan arah sehingga peluru bisa menembus apa yang dituju.

Dwi Tunggal Siwa-Buddha ini bisa disepadankan dengan Filsafat Samkhya tentang Purusa dan Prakrti. Menurut Samkhya, alam semesta ini tersusun dari dua entitas yang berbeda, yakni unsur kesadaran (Purusa) dan unsur materi (prakerti), sehingga dikenal sebagai filsafat dualis (Sen Gupta, 1986: 6). Prakṛti dan Purușa adalah Anādi (tanpa awal) dan Ananta (tanpa akhir; tak terbatas). Ketidakberbedaan (Aviveka) antara keduanya merupakan penyebab adanya kelahiran dan kematian. Perbedaan antara Prakṛti dan Purușa memberikan Mukti (pembebasan). Baik Prakṛti maupun Purușa adalah Sat (nyata). Purușa bersifat Asanga (tak terikat) dan merupakan kesadaran yang meresapi segalanya dan abadi. Sharma (1997: 155-157) menyatakan bhawa Purusa adalah Sang Diri yang bersifat transendental atau kesadaran murni. Dia bersifat absolut, independen, bebas, tak bisa dipersepsi, tidak bisa diketahui oleh agen lain, berada di atas pemahaman pikiran dan tak bisa dijelaskan oleh kata-kata. Purusa senantiasa murni, kesadaran non-atributif. Purusa tidak diciptakan dan tidak pula menciptakan. Tidak seperti filsafata Advaita Vedanta atau Purva Mimamsa, Samkhya percaya dengan pluralitas Purusa.

Prakṛti merupakan penyebab pertama dari alam semesta material yang memanifestasi, kecuali Purusa. Apapun yang bersifat, fisik baik berupa pikiran, energi maupun materi semuanya adalah Prakṛti. Prakṛti adalah asas materi yang terpengaruh oleh 3 Guṇa atau sifat, yaitu Sattvam, Rājas dan Tamas. Prakṛti artinya 'yang mula-mula', yang mendahului dari apa yang dibuat dan berasal dari kata "Pra" (sebelum), dan "Kri" (membuat) yang mirip dengan Māyā dalam Vedānta. Prakṛti merupakan sumber dari alam semesta dan ia juga disebut Pradhāna (pokok), karena semua akibat ditemukan padanya dan juga merupakan sumber dari segala benda.

Pradhāna atau Prakṛti ini adalah kekal, meresapi segalanya. Ia tak memiliki sebab tapi merupakan sebab dari suatu akibat. Prakṛti hanya bergantung dari pada aktivitas dari unsur pokok Guna-nya sendiri. Akibat dari pertemuan antara Puruṣa dan Prakrti timbullah ketidak seimbangan tri guna tersebut yang menimbulkan evolusi atau perwujudan. Prakṛti berkembang dibawah pengaruh Purușa. Produk awal dari evolusi Prakṛti adalah Mahat atau Kecerdasan Utama, yang merupakan penyebab alam semesta dan selanjutnya muncul Buddhi dan Ahamkāra. 
Dari Ahamkāra muncul Manas atau pikiran, yang membawa perintah-perintah dari kehendak melalui organ-organ kegiatan (Karmendriya). (Adhi, 2015, dalam: wisdanarananda.blogspot. co.id). Secara keseluruhan filsafat ini memiliki 25 unsur atau tattva yang dapat digambarkan sebagai berikut.

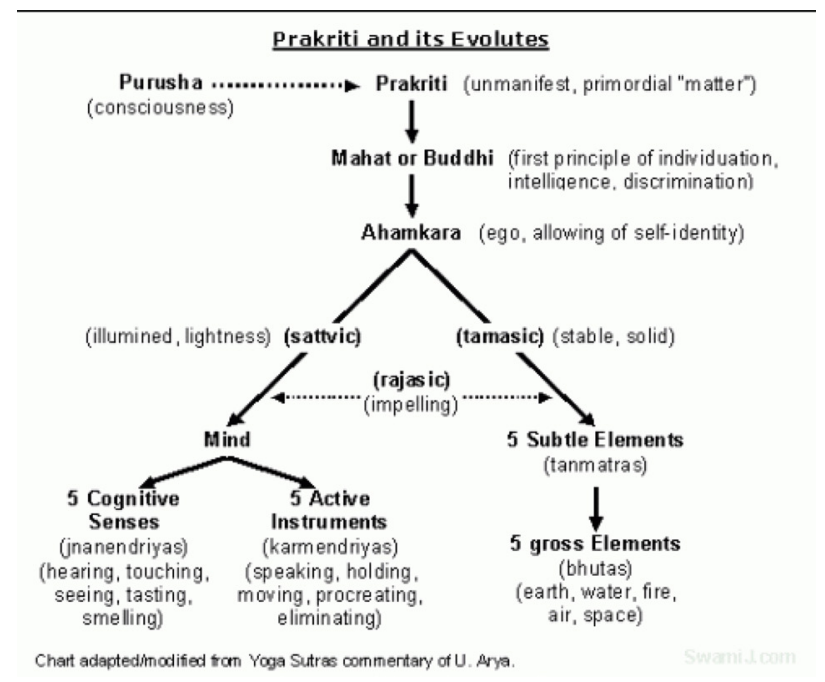

Sumber: knowingyoga.wordpress.com

Prinsip Dwi Tunggal Siwa-Buddha mengidentifikasi bahwa keseluruhan asas material yang ada adalah Siwa. Unsur Prakrti dan turunannya bisa diidentikkan dengan Siwa. Sementara unsur Purusa bisa diumpamakan dengan Buddha. Purusa adalah unsur non-material, demikian juga dengan Buddha. Apa yang menjadi atribut dari Purusa juga merupakan atribut dari Buddha. Sehingga dengan demikian filsafat Samkhya hampir mendekati dengan prinsip dwi tunggal Siwa-Buddha dari komunitas Bahung Tringan Desa Bebandem, Karangasem. Namun ada satu hal yang membedakan dari kedua sistem filsafat tersebut secara eksistensi.

Filsafat Samkhya bersifat dualis, yakni masing-masing dari kedua unsur Purusa dan Prakerti tersebut adalah independen, berdiri sendiri. Purusa adalah unsur kesadaran dari alam semesta, sementara Prakerti adalah unsur materi. Keduaduanya berdiri sendiri. Ketika keduanya terjadi kontak yang menyebabkan unsur Tri Guna tidak seimbang, Prakerti kemudian mengalami evolusi sampai terbentuk unsur yang paling kasar, yakni Panca Maha Buta. Sementara di dalam prinsip
Dwi Tunggal Siwa-Buddha Bahung Tringan, Siwa dan Buddha tidak berdiri sendiri, melainkan Buddha sendiri lahir dari Siwa. Kesadaran murni (Buddha) lahir dari unsur materi yang mengalami pergesekan. Hal ini dapat digambarkan seperti gambar di bawah ini.

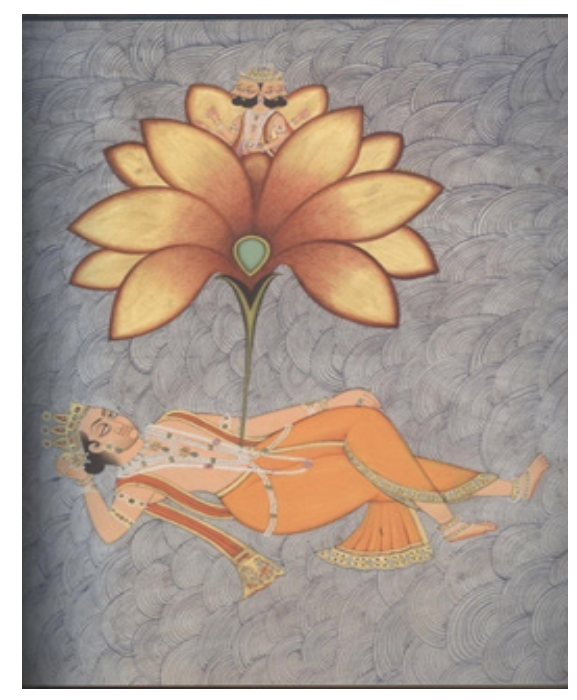

Brahma tiba-tiba muncul dari pusar Dewa Wisnu di atas bunga daun padma

Sumber: venetiaansell.wordpress.com

Lahirnya Buddha dari Siwa dalam prinsip Dwi tunggal Siwa-Buddha Bahung Tringan mirip seperti apa yang dinyatakan di dalam Bhagavata Purana tentang lahirnya Dewa Brahma dari pusar Dewa Wisnu. Brahma lahir pada saat waktu dan alam semesta lahir, di atas sebuah lotus yang akarnya berada di dalam pusar Dewa Wisnu (Anderson, 1967: 31-33). Bhagavata Purana menyatakan bahwa Brahma pada awalnya kebingungan, tertidur, keliru dan untuk sementara tidak kompeten karena Dia terjebak di dalam alam semesta. Dia kemudian sadar dari kebingungan dan terbangun dari tidurnya, bermeditasi menjadi seorang pertapa. Akhirnya Dia menyadari Tuhan didalam hatinya, melihat awal dan akhir alam semesta, dan kemudian kekuatan kreatifnya hidup kembali (Anderson, 1967: 28-35).

Prinsip Dwi Tunggal Siwa-Buddha dalam konteks atribut dan hubungan antara atman dan Brahman dapat disamakan dengan sistem filsafat Vishishtadvaita Vedanta. Menurut sistem yang dikembangkan oleh Ramanuja 
Acharya tersebut melihat bahwa totalitas dari ketiga Tattva (pengetahuan atas tiga entitas riil): Ishvara (Parambrahman, Wisnu/Tuhan), Jiva (chit, sentient) dan Alam semesta (achit, insentient) adalah Brahman. Ishvara adalah bagian substansi dari Brahman sementara Jiva dan alam semesta adalah atribut dari Brahman. Ishvara adalah maha kuasa, maha sempurna, maha mengetahui, dan pencipta seluruh alam semesta. Atman pada prinsipnya tidak berbeda dengan Brahman tetapi posisinya hanya sebagai atribut bersama dengan seluruh alam semesta (benda mati), sehingga ajaran ini juga disebut dengan monisme atributik. Ibarat bunga mawar dengan warnanya, keduanya tidak dapat dipisahkan namun yang satu sebagai substansi sementara yang lainnya sebagai sifat atau atributnya. Bunga mawar merah misalnya, bunga mawar adalah substansi sementara warna merah adalah atributnya. Keduanya berdiri sendiri tetapi tidak dapat dipisahkan. Jiwa berbeda dengan Brahman, tetapi keberadaannya tergantung dariNya. Hubungan ketiga tattva tersebut dapat digambarkan sebagai berikut.

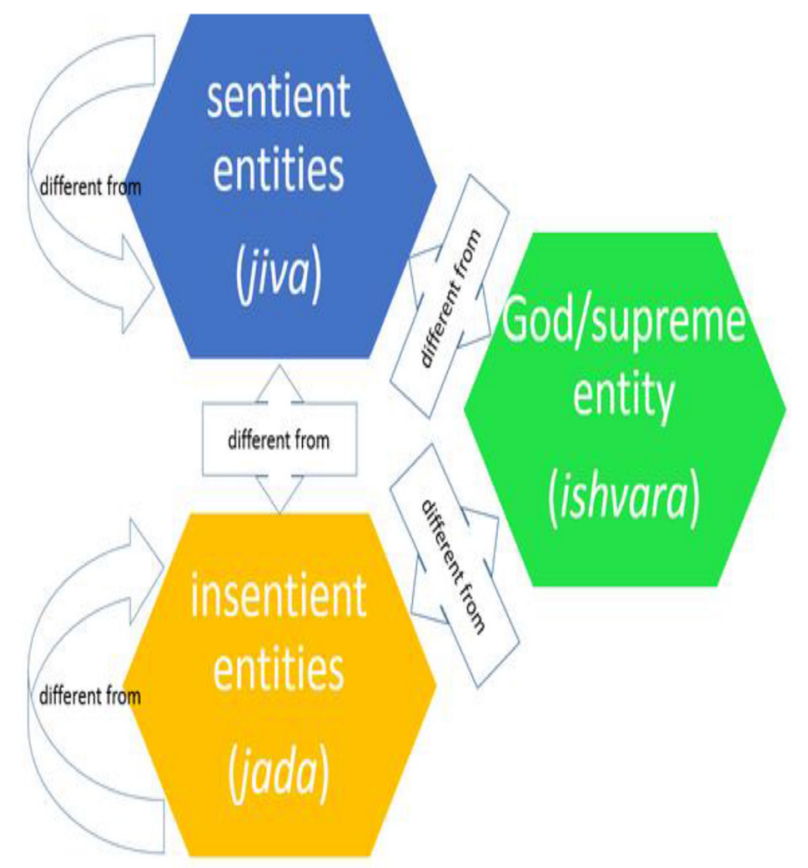

Ishvara, Jiva dan alam semesta (Jada) sebagai tiga entitas yang berbeda.

Sumber: www.quora.com
Prinsip Dwi Tunggal Siwa-Buddha percaya bahwa jiwa dan alam semesta ini nyata adanya. Tuhan adalah maha kuasa, yang memiliki segalagalanya, maha pengasih dan maha penyayang. Jiva, para Dewa, dan seluruh alam semesta beserta isinya adalah Tuhan (Brahman). Hal yang membedakan dengan sistem Vishishtadvaita ini adalah bahwa Jiva, para Dewa dan seluruh alam semesta bukanlah entitas yang berdiri sendiri. Menurut Ida Wayan Jelantik Oka, Jiva (atman) adalah percikan kecil dari Tuhan (Brahman). Atman dan Tuhan adalah tunggal, tidak berdiri sendiri, sehingga baik jiwa maupun alam semesta adalah Braman itu sendiri. Jiva muncul dari Brahman, demikian juga alam semasta ini muncul dari badannya Brahman. Ida Wayan dalam wawancara (Sabtu, 23 Juli 2016) mengatakan sebagai berikut.

Jiwa yang dimaksud adalah atman, yang merupakan diri sejati, yang hakikatnya sama dengan Sangkan Paraning Dumadi (Brahman, Tuhan) itu sendiri. Jiwa pada prinsipnya adalah Beliau itu sendiri. Demikian juga dengan seluruh alam semesta beserta isinya ini muncul dari proses emanasi, dimana dari dalam Brahman itu sendiri alam semesta ini muncul. Alam semesta ini adalah bagian dari tubuh Tuhan itu sendiri, tetapi sifatnya tidak sadar. Sementara atma sifatnya sadar. Atman dan Brahman itu satu, tetapi wujudnya bisa dipanggil kembali atau hadir kepada orang-orang tertentu yang sedang menjalani proses spiritual dengan menjadi guru niskala turun kembali dalam wujud awatara.

Jiwa (atman) muncul dari Brahman dan kemudian juga akan kembali menyatu denganNya. Ketika jiva telah turun dan mendapatkan badan, maka jiva diselimuti oleh kebodohan (avidya), sehingga Ia tidak lagi ingat dengan sumber aslinya. Kehidupan ini adalah untuk kembali menyadari bahwa Diri Yang Sejati ini adalah Sangkan Paraning Dumadi (Asal mula dari segala sesuatu yang termanifestasi) itu sendiri. Jiva dan Brahman dalam prinsip Dwi Tunggal SiwaBuddha adalah satu sebagaimana yang dianut oleh sistem Advaita Vedanta, namun tidak mutlak 
bahwa yang ada hanya Brahman saja. Meskipun Jiva telah menyatu kembali ke Sangkan Paraning Dumadi, sewaktu-waktu saat diperlukan jiwa yang pernah mengambil wujud itu bisa lahir atau dipanggil kembali dalam wujudnya yang sama.

\section{Penutup}

Konsep teologi Dwi Tunggal Siwa-Budha berbeda dengan perkembangan dan penyatuan agama Hindu dan Budha di Jawa. Perbedaannya terletak pada susunan unsur-unsurnya, yakni dalam perkembangan penyatuan Siwa dan Budha di Jawa, terutama di era Majapahit, Siwa dan Budha dijadikan sebagai objek atau tujuan pemujaan. Dalam agama Hindu, Siwa dijadikan objek pemujaan tertinggi, demikian juga Sang Buddha.

Pada jaman itu, Siwa dan Budha dikatakan tunggal, yakni dia yang memuja baik melalui Siwa maupun Budha akan mencapai tujuan yang sama. Sementara itu dalam prinsip Dwi Tunggal Siwa-Budha dalam Meditasi Kesadaran Budhi Bahung Tringan, Siwa dan Budha bukanlah sebagai objek pemujaan, melainkan suatu wilayah atau penyebutan dari sebuah tahapan yang dicapai atau dialami oleh seorang sadhaka yang larut dalam olah spiritual. Siwa disamakan dengan segala sesuatu yang bersifat fisik atau wadah dari segala yang ada. Demikian juga Siwa merupakan tempat dari berbagai aktifitas, sebab dualitas ada di wilayah ini. Ketika seseorang berlatih meditasi, unsur dualitas ini mengalami pertemuan, khususnya unsur positif dan negatif dalam pikiran. Saat keduanya bertemu, maka timbullah kevakuman. Dalam kondisi vakum, jnana atau kecerdasan tinggi muncul. Kecerdasan tinggi inilah yang mengantarkan seseorang menuju alam Budha. Sehingga dengan demikian wilayah Budha merupakan vakumnya unsur dualitas Siwa.

Wilayah ka-Budha-an dapat dicapai oleh roh yang telah diproses secara spiritual. Oleh karena itu, proses roh merupakan hal yang utama dalam prinsip Dwi Tunggal Siwa-Budha ini. Roh orang biasa yang belum berspiritual maupun orang yang mempelajari kadiatmikan masih berada dalam wilayah Siwa, sebab semuanya itu masih bersifat fisik. Ketika fisik itu bisa dilampaui, alam Budha baru bisa diraih. Namun, proses roh ini hanya mungkin terjadi hanya ketika memiliki badan. Tanpa badan roh tidak bisa diproses oleh karean piranti ka-Siwa-an dari roh itu tidak ada. Proses roh memungkinkan terjadi berkat bantuan dari unsur Siwa.

\section{Daftar Pustaka}

Adhi, Ketut. 2015. Filsafat Samkhya. Dalam: wisdanarananda.blogspot.co.id. Diunduh: 15-08-2015.

Anderson, Richard. 1967. Hindu Myths in Mallarmé: Un Coup de Dés, Comparative Literature, Vol. 19, No. 1.

Phalgunadi, I Gusti Putu. 2013. 'Perkembangan Siwa-Buddha di India dan Indonesia Pendekatan Ilmu Sejarah'. Disampaikan dalam acara Rembug Sastra di Pura Agung Jagatnatha. Denpasar.

Sen Gupta, Anima. 1986. The Evolution of the Samkhya School of Thought, New Delhi: South Asia Books.

Sharma, C. 1997. A Critical Survey of Indian Philosophy, New Delhi: Motilal Banarsidass Publication.

Suamba, I.B. Putu. 2007. Siwa-Buddha di Indonesia Ajaran dan Perkembangannya. Denpasar: Program Magister Ilmu Agama dan Kebudayaan Kerjasama dengan Penerbit Widya Dharma.

Widnya, I Ketut. 'Pemujaan Siwa-Buddha dalam Masyarakat Hindu di Bali'. Jurnal Mudra 22 (1): 39-54. 2008. Denpasar.

Informan

Nama : Ida Wayan Jelantik Oka

Umur : :67 tahun

Pekerjaan : Pinisepuh Komunitas Bahung Tringan

Asal : Bebandem, Karangasem 